University of Louisville ThinkIR: The University of Louisville's Institutional Repository

Electronic Theses and Dissertations

$8-1949$

\title{
History of the King's Daughters Home for Incurables, Louisville, Kentucky, 1909-1948.
}

Clyde H. Van Metre Jr.

University of Louisville

Follow this and additional works at: https://ir.library.louisville.edu/etd

Part of the History Commons, and the Social Work Commons

\section{Recommended Citation}

Van Metre, Clyde H. Jr., "History of the King's Daughters Home for Incurables, Louisville, Kentucky, 1909-1948." (1949). Electronic Theses and Dissertations. Paper 3252.

https://doi.org/10.18297/etd/3252

This Master's Thesis is brought to you for free and open access by ThinkIR: The University of Louisville's Institutional Repository. It has been accepted for inclusion in Electronic Theses and Dissertations by an authorized administrator of ThinkIR: The University of Louisville's Institutional Repository. This title appears here courtesy of the author, who has retained all other copyrights. For more information, please contact thinkir@louisville.edu. 
NAME OF STUDENT: Clyde H. Van Metre, Jr.

TITLE OF RESEARCH PROJECT: HISTORY OF THE KING'S DAUGHTERS HOME FOR INCURABLES, LOUISVILLE, KENTUCKY, $1909-1948$

APPROVED:

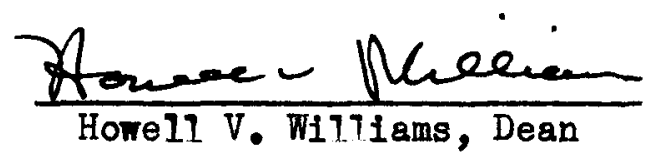

DATE: Quguat 24,1949. 
UNIVERSITY OF LOUISVILIE

HISTORY OF THE KING'S DAUGHTERS

HOME FOR INCURABLES

LOUISVIJJIE, KENTUCKY, 1909-1948

\author{
A Research Project \\ Submitted to the Faculty \\ Of the Raymond A. Kent School of Social Work \\ In Partial Fulfiliment of the \\ Requirements for the Degree \\ Of Master of Science in Social Work
}

By

Clyde H. Van Metre, Jr。

1949 


\section{ACKNOWLEDGEMENT}

Grateful acknowledgement is made to Mrs. E. P. Ernwein, President, The KIng's Daughters Home for Incurables and other members of the Board of Directors for their kind assistance in the preparation of this study. 
TABTE OF CONTENTS

Chapter

Page

I. INTRODUCTION .................. I

II. ESTABLISHMENT OF THE HOME, 7909-1971 ....... 7

III. EXXPANSION OF THE PROGRAM 1912-1928........ 74

IV. DEVETLPMENT OF SERVICES 7928-1948 . . . . . 20

V. SUMMAKY AND CONCTUSTONS .............. 26 APPENDIXES .................. 32

Appendix A: Original Articles of Incorporation, The King's Daughters Home for Incurabtes, Apri1 28, 1909......... 32

B: Amended By-Laws, The King's Daughters Home for Incurables, October 8, 1948 . . 35

C: Articles of Amendment, The King's Daughters Home for Incurabies, October 8,1948 ............. 57

D: Presidents of The King's Daughters Home for Incurables . . . . . . 62 BIBIIOGRAPHY ....................... 63 


\section{CHAPTER I}

\section{INTRODUCTION}

This study traces the growth and development of The King's Daughters Home for Incurab?es, Iouisvil7e, Kentucky, from its beginning up until the end of 7948 and looks forward to future plans that may seem appropriate. Members of the Board of Directors desired such a study be made as a means of drawing together the past work of their organization. They also looked to the study as being a help in making future plans for the continuation of their work. Prior studies made on various phases of the institution were made in 1924 (Haven Emerson Survey) ${ }^{1}$ and in 1940 (Health and Welfare Council Survey) ${ }^{2}$ for administrative purposes. In 1948 the work of the home provided the material for two theses in the Kent School of Social Work, University of Louisville. One was a study of the rehabititation in the institution. ${ }^{3}$ The other was a study of the applicants served by Family Service Organization in 1946 and 1947.4 Other written material inc'udes brief notations of services rendered by the institution as it meets the need for the incurable i 17 or handicapped person. There has been from time to time short sketches printed for publicity during fund raising drives.

\footnotetext{
IHaven Emerson and Anna C. Phi Tips, Hospitals and Health Agencies of Louisvil1e, 1924. A Survey (Louisvi 17e, Community Chest, 1925). 2Report of the Hea?th Council Committee on "The Chilaren's Program at the Home for Incurables", November, 1.940.

3 Gretna Lillian Brown, "The Place of Rehabilitation in the Home for Incurabies". Unpublished masters thesis, Kent School, University of Louisvi $17 e, 1948$.

4Elizabeth Conder Lewis, "A Study of One Hundred and Forty King's Daughters Home for Incurables Applicants served by Family Service Organization Junuary 1, 1946 - December 31, 2947". Unpublished masters thesis, Kent School, University of Iouisvilie, 1948.
} 
As little as has been written on the history and development of an institution that has been meeting a definite need in the community and state, it is the purpose of this study to bring this material together in an orderly historical survey before much of the material is lost or mislaid. Much of the source materia? was scattered through the minutes of the Board of Directors Meetings, Executive Committee Meetings, Admission Committee reports and the reports of other groups connected with the operation of the institution. The minutes are fast becoming illegible through fading, yellowing and crumbing with age. Several were past being read at this point as the ink was blurred as a result of the flood in 1937. It was also found many of them were indefinite and incomplete and some attempt was made to complete this by personal contact with nembers associated with the Home. Newspaper clippings and mimeographed bulleting proved to be a valuable source of material. They have been saved over the years with the idea of being made into a scrap book.

The historical method of research is used on the project. As it is to be primarily a study of past events it depends on data already recorded or contacts with people closely associated with the Home.

In Chapter I, the introduction covers the purpose of the stuay, the time covered, and the importance of the historical data on The King's Daughters Home for Incurables. The sources of this information are given. Reviews of prior studies made are listed.

Another section in Chapter I gives a brief history of The International order of the King's Sons and Daughters as it is felt this material necossary for the full understanding of the work of this Home and its operation. Following this is the organization of members of 
the order in Kentucky and their initial work with the "sick poor" in the city prior to the time the Home for Incurables was decided on as being the project for the state work.

Chapter II includes the events during the period 1909-1911. It was during this period the actua? operation of the Home started. Prior to this the King's Daughters nurses in visiting the sick poor saw the need for such an institution for incurable people. The early struggle of the members to establish the Home for Incurables is discussed. The organization and management of the home is covered. Chapter III includes the period from 1911-1928. During this time the growing need for more space resu'ted in two expansion programs and many additional services.

Chapter IV includes the period from 1928-1948. During this time the depression of the early thirties and in 1936 a misappropriam tion of funds caused financial difficulties for the Home. The many services the organization does for the welfare of the patients is pointed out. It was during this time that the decision not to accept children was made. There was also the need recognized for a trained social worker in the Home and plans made for this service.

Chapter V includes a summary of the development of The King's Daughters Home for Incurabtes and those conclusions that might be made from past events.

"The King's Daughters" was forma7ly organized on January 13, 1886. There were ten women in the original group and to four we own much credit for the organization. They were Mrs. Margaret Bottome, Mrs. Mary Jowe Dickinson, Mrs. Theodore Irving, and Mrs. I. C. Davis. Mrs. Bottome was greatly interested in the young people of her husband's 
parish and she did much to pubticize the Order through her page in "The Ladies Home Journal". Mrs. Irving was head of a New York school for girls. Mrs. Davis had been on the foreign mission field and was much interested in socia? reform. Mrs. Dickinson was an educator, journalist, novelist and poet; supremely interested in young people and with a profound belief in their powers and possibilities for good. After much consultation between these friends a meeting was called at Mrs. Bottome's home in New York City, and the Order was born. 5

The object of "The King's Daughters" was "to develop spiritual. Iife and to stimulate Christian activities;" anyone might become a member who was "in sympathy with this object and held himself responsible to The King, our Iord and Savior, Jesus Christ." These articles"object" and "membership" - were part of the first constitution adopted, and have never been changed.

The Kingis Daughters were among the first - if not the very first - organizations to draw together women of different denominations for common religious, educational and social work.

The new society grew apace. One of the facts that are emphasized was that every person - young or old, rich or poor, wise or ignorant - has been given by God a place and a part in the establishment of His Kingdom on earth. Each member was urged to "lend a hand whenever the Master cal1s." The badge of membership was the purple ribbon or the silver Maltese Cross, engraved with the initials I. H. N. and bearing the date 1886. The chosen motto:

\footnotetext{
5Monehouse, Clara, "A Short History of the Order", The Silver Cross, X (July, 7.924), p. 9.
} 
Look up and not down

Look forward and not back

Look out and not in

And lend a hand,

represents the attributee of faith, hope, and altruistic service, which should characterize members of the Order. The watchword chosen was:

In His Name

and the text:

Not to be ministered unto, but to minister. 6

Men and boys were so eager to join the new society that in 1887 the name was changed to include "Sons" and the "Order of The King's Daughters and Sons" was incorporated in 1888 with headquarters in New York City. In 1891 the title was changed to "The International Order of The King's Daughters and Sons."

The Order unit was called a Circle and might consist of any number from two up. Each Circle, like each member, was free to choose its own work and to carry it on in its own way. No rules were laid down - onl.y the solid foundation of allegiance to The King and the service to His children; on this each could build according to circumstances. An amazing diversity of methods and work, with a common aim, is the characteristic of the Order. Simplicity was one of the Order's keynotes. Its members were urged to look after "the little things that count", to feel a personsl responsibility for any need they might see, to welcome opportunity for service a high priviledge.

Kentucky first heard of The King's Daughters when Mrs. Fannie Casseday Duncan came home from Philadelphia wearing the silver cross. She had heard of the society while visiting in the East, became interested

6Gugle, Sara F., History of The Internationa? Order of The King's Daughters and Sons (Columbus, Stoneman Press, 1931), p. 23. 
and jolned. When she came home and told her sister, Miss Jennie Casseday, about it, she too joined. So these two were the first members of The King's Daughters in Kentucky.

In Apri1, 1887, a year later, Dr. Annie Veech of Louisvi 17e, a young school girl, having heard of the organization, interested a number of young friends and together they went to Miss Jennie Benedict and asked her to form a Circle for them and be their Leader. As Miss Benedict could not decide the type of work she asked the assistance of Miss Casseday. A7though an invalid and great sufferer, Miss Casseday a] ways took an interest in we? fare work. After much consideration, they decided the Circle should undertake to nurse the sick poor of the city. It was with this smal? beginning of ten school girls that the District Nurse work was first started in Louisville.

By 1892 there were fourteen Circles in the city and they were talking over plans for a more definite work in order that the poor and suffering might have at least a portion of their burdens 1ifted. 7 It was in this work of the visiting nurses that we find the earliest beginning of The King's Daughters Home for Incurables. 
During the early years in nursing the "sick poor" by the King's Daughters it was found the state had no place where people with incurable diseases could be taken. Destitute persons with incurable diseases or disabilities presented one of the major problems the community faced in its socia? routine. The lack of any pubric provision for incurable invalids placed unfair demands on the district nurse organization. It also resulted many times in the person getting inadequate treatment or placing abnormal family conditions that handicapped other members. Because of this need the King's Daughters decided to wage a campaign for the establishment of an institution for incurable persons.

The facts were presented to the State Convention that met in Frankfort, Kentucky, in November, 1908. This convention voted to establish a Home for Incurabies and made the initial plans for the future meetings.

On February 25, 1909, a 7arge and enthusiastic conference was held at State Headquarters, Louisville, by the state officers, the executive boerd, and representatives from the Circles throughout the city and state to discuss plans for the Home for Incurables, the new state work for the King's Daughters. At this meeting it was decided the institution woutd be located in Louisvil?e. 1

lMinutes, Board of Directors, King's Daughters Home for Incurables, Louisville, February 25, 1919. 
A finance committee was organized to make arrangements and take pledges for the support of the Home. The first contribution to the new home was fifteen dorlars in nickles and dimes that had been collected in the past three years by Miss Kate Jenkins, King's Daughters nurse, from the incurable patients she attended. They gave this hoping it would be used to form an institution for incurables. Another gift of two dollars and a half was received from an inmate of the Home for Aged and Infirm, who had died, and in dying had asked that this sum be used "to buy a pillow for some weary head." Another gift was a thousand dollar gold bond, left from the sale of the Jennie Casseday Infirmary, which had belonged to the Touisvi l.e Union of the King's Daughters. Various Circ?es throughout the state pledged money for support of the Home.

At the first meeting a president, Custodian of Funds, and a Board of Directors were elected to conduct business untir more definite arrangements could be completed. The present state officers were to be a part of the administrative board for the institution.

The house committee was formed at the first meeting and were ready to make their report at the Aprit 15, 1909, meeting. At this meeting the following report was given.

After consulting with many (at least 12) of Real Estate firms of our city find that the most suitable property for the purpose of such a home is located in the Highlands at the corner of Stevens and Norris Avenues. The price of the property is $\$ 6,000$, the terms recorded in the contract. We can get immediate possession of the property. The front of the lot on Stevens Avenue is 306 feet, running back 150 feet to a lot adjoining. The property has avenues on three sides making it valuable if we should wish to sell lots off the main property. It has a large rather old fashioned house on it of 12 rooms. The rooms are so large that they al1 or at least six of then could be made into two rooms each. It has an almost new large stable with good second story which 
could be made into four rooms. It has a wire fenced chicken yard and good pasturage could be obtained on adjacent lots for a cow. A sewer is now being made in Norris Avenue to connect with the main big sewer of the Highlands in Eastern Parkway Drive. There is a large clear cistern near the kitchen door full of cold clear water which was filled after the roof was thoroughly washed during the winter rains. There are electric 7ights, gas, and city water at the corner of Stevens and Norris Avenues. The streets and sidewalks are now of cinders and not paved. If they were the property would be worth $\$ 9,000$. It is very unusual to get property when only $7 / 6$ of its value is required as first payment as in the case of this property. Usual? $7 . / 3$ or $1 / 4$ is required as 7st payment. The house is splendidiy built and in good repair, the house having been papered just a year ago. There is a high basement of heavy sp?endid stone work under the entire building making it dry and healthy. The e? evation of the home is the highest in the city, it is high as the mater works in Crescent Hill, therefore, above the smoke of the city and as free from dust and soot as if miles in the country. It has all the good advantages of the city near its doors.

We, therefore, for the above reasons recommend this property to the board for our Home for Incurabies. 2

This property was approved by the board and plans moved ahead toward the purchase. Reports of the finance group indicated more funds would be needed and it was hoped the public could be interested in this work.

The King's Daughters while making plans for the institution were drawing up a constitution but courd not complete this unti? they were incorporated. Mr. Robert Bingham was asked to prepare the incorporation papers. They were completed and filed on April 28, 1909.

They decided the name of the institution would be "The Home for Incurables" founded by the Kentucky Branch of the King's Daughters and Sons.

The original Articles of Incorporation specified that "the object of this charity, which is non-sectarian, is to provide a home 
for persons who are residents of the State of Kentucky, who are aff7lcted with an incurable physical disability or disease." 3

July 2, 1909, was set as the probable date for the Home to be opened. Prior to this date many detaits of furnishing, decorating, securing staff, and other arrangements were made by the King's Daughters. Kitchen and linen showers helped supply the house. Several members donated furniture for a room or a part of room.

There was a large crowd to attend the dedication service he?d on July 10, 1909. Every religious denomination in the city was represented at the dedicatory exercises at the new Home for Incurables founded by the King's Daughters and Sons, and the on7y home for Incurables north of Louisiana and west of West Virginia. 4

At the time the home was ready to open there were eighteen applications on file. The first two patients were a 60 year old woman and her invalid son. The mother entered the institution "to have some time to rest before she passed away," but lived twenty years. The invalid son died eighteen months after his admission. Other patients were soon admitted and brought the number up to full capacity of twenty patients. As it became known throughout the state, a waiting list began to grow.

Soon after opening, the board asked the people to drop the word "Incurable" from the title of the Home as it had such a depressing effect upon the pubric. They requested the institution be spoken of as The King's Daughters Home.

3 Articles of Incorporation, King's Daughters Home for Incurables, Louisvi?7.e, dated April 28, 1909, office of the clerk of the county court, Jefferson County, Kentucky.

4The Courier-Journal, Louisville, July 11, 1909. 
When patients were accepted the members proceeded to make it "a real home" where they cou?d be as comfortable as possib?e with their disabilities. A new hot air furnace was installed and a staff of physicians from the city was organized to give free service to the patients. Electric lights were installed and a system of call bells. Rules for the patients and staff were made. Devotional services were planned for each week. They felt religion was increasingly important to the individual whose life is limited.

During the first year manyigifts were received from people interested in the work. These include a cow, chickens, car road of coal, Tinen, food supplies, furniture, clothing and medical supplies. The matter of finance was a constant struggle and often there was not enough money to meet current bills. Funds were raised by lawn fetes, entertainments, donation parties, proceeds from baseball games, and private donations. When al? this failed to meet the need the board decided it would be necessary to ask the city or state for financial help.

In February 1970 a bil7 was presented and passed in the State Legistature making an annua? appropriation of $\$ 70,000$ for the Home. This assured the operation of the institution cou'd continue the care of the incurabie persons in need of this type of care. The State Legislature could make this grant because there was no public institution to meet the needs of the incurabie needy person. 5

The management of "The Home for Incurables" was vested in a Board of Directors in the original articles of incorporation dated Apri] 28, 1909. The articles of incorporation were amended on November 
6, 1931, September 13, 1935, and revised on October 8, 1948, but the general structure remained essentially unchanged.

The following statement is a quotation of Section VIII of the Artic es of Incorporstion amended on October 8, 1948.

The business and affairs of said corporation shall be managed and conducted by a Board of Directors, which shall have continuing power to redelegate its powers and authority to committees, officers and representatives of the corporation, to rescind and abrogate alr such redelegations, and to make, amend and repea? By-Laws governing the manner in which the business and affairs of the corporation sha? ? be conducted. The elegibility qualifications of the members of said Board, the number of directors to constitute said Board, the time and place of their election, the duration of their terms of office and manner of filling vacancies on the directorate shall be prescribed by the By-Laws. 6

According to the By-Laws, adopted October 8, 1948, the officers of the Board of Directors along with the chairman of the Standing Committee, the Branch President, three members of the Board of Directors se?ected by said Board from their own number, all tife Members, and Custodian of Funds sha? compose the Executive Comnittee and supervise the operation of the Home. The Executive Committee shat? authorize the expenditure and investment of alr funds, and sharr select and designate the members of the Admissions, House, Re7igious Work, Occupationa? Therapy, Entertainment, Finance and By-Laws Committees. The Executive Committee employs the superintendent and the bookkeeper or engages such services. They shall have the corporation's books audited by a competent auditor and accountant each year. This committee appoints the Medica? Staff and selects a Medica?. Coordinating Committee. On the recommendation of the Admissions Committee shall employ a social worker

6articles of Incorporation, King's Daughters Home for Incurables, as amended 0ctober 8, 1948, of fice of the clerk of the county court, Jefferson County, Kentucky. 
and on the advice of the Occupationa? Therapy Committee may employ a therapist. 7

The members of a? committees serve on a voluntary basis without pay. It is prescribed in the By-Laws that all. members of the Board of Directors shall pay a membership fee of one dollar a year. It is necessary that all these members give a large portion of time to operate the institution. 


\section{EXPANSION OF THE PROGRAM 1912-1928}

The King's Daughters accepted the Home for Incurables for their state work in 1.908 and in 1909 established a home that could care for twenty patients. After the first year of operation, it was found more funds woutd be needed to carry on this project and a state appropriation of $\$ 10,000$ yearly was secured. The institution was soon filled, with a ralting list for persons seeking admission. Because of this it was fert some addition must be made.

An Advisory Board of seven men was formed and investigation made as to possible changes in the building. It was suggested that the roof be raised to make more room. The state inspections in 1912 advised the purchase of additionat ground for the enlargement of service. Three lots were purchased adding a ground space of one hundred fifty feet by five hundred ninety feet.

In order to be better informed about the operation of the Home the Board of Directors sent two members to visit other institutions in the East and North. In this way they could compare their service with that offered in other cities.

The first national convention of The International King's Daughters and Sons was held in touisville in 1912 and this meeting stimulated the local group in such a way that its influence was felt for many years. 1

In June, 1913, the Home came into possession of a legacy of 
$\$ 5,000$. Having duly examined the question of enlargement and aided by the advice of the Advisory Committee of business men, the Executive Committee decided to take immediate steps for entarging and improving the entire place. 2 The addition would include a much needed ward for children and accommodations for twice as many adult patients.

In December of 1913 the building addition was ready for dedication and this brought the capacity up to forty patients. Practicarny all of the money to pay for this $\$ 14,000$ addition was secured prior to the time it was to be occupled. The rooms were all furnished by the King's Daughters Circle. 'The number of persons on the waiting list was enough to more than fill the new quarters.

A resident intern was secured from the medical school to live in the Home and look after the patients in exchange for room and board. He was under the Medical Staff and responsible to them.

After the new addition was added, it was imperative than an elevator be added for the comfort and use of the patients and staff. The members erected one in memory of their Mothers.

The members of the various committees spent much time in seeing that the needs of the patients were met. Religious services were provided each week. Other groups came to the Home and provided various forms of entertainment. A personal interest was taken in each patient and reports on their conditions given to the meetings at stated intervals. The Admission Committee was especially active as there was a) ways a waiting list to be investigated. These investigations required much time of various members and required visite to al1 parts of the state. A very accurate list was kept and reports given to the 
Board of Directors at each meeting. Each year brought new problems but the King's Daughters bravely worked through the many difficulties to render a high quality of persona? service.

In 1918 the Home for Incurabies became a part of the Louisville Federation of Social Agencies and received over $\$ 6,000$ that had been raised in a joint fund drive. 3 The income from the King's Daughters and the state appropriation were inadequate to meet the need for the operation of the Home. The success of the joint drive for funds in 1918 prompted it being continued. It was continued under the name of The Welfare League of Louisville until. 1923 when the name was changed to the Community Chest. During these years the Home for Incurables secured financial support from the League and continued a member of the Community Chest.

The first automobile was acquired in 1919 and funds for 1 ts operation were secured by patients and members making tobacco sacks for one of the factories in the city. Each addition in equipment in the Home was often financed by means other than including it in the budget.

In 1921 the appropriation for the Home for Incurables was omitted from the Budget Appropriation Committee list and it was necessary to have a separate measure passed in the Legislature. All members of the Order in the state were especially active in seeing this bil7 was passed. It was pointed out at this time that the Home cared for a class of incurabiy ill and afficted persons which the State makes no provision. In the twelve years the home had been in operation, one hundred and thirty-one men, women and chitdren had been or

3The Community, (Vol. 11, No. 2, Louisvil?e, Welfare League, February 1919), p. 2 . 
were being cared for, representing thirty-two counties in Kentucky. The waiting list contained sixty names and nineteen died in 2927 white waiting admission. 4

Shorty after the close of World War I the Board became interested in the possibilities of occupational therapy for the patients. At first this work was conducted by various people giving time on a part-time basis. Tater a graduate of the Boston School of Occupationa? Therapy was employed jointly by the Children's Free Hospital and Home for Incurables. The work at this time was limited due to lack of space for such activities and it was not until after the building expansion in 1927 was a separate room provided. When this was added it provided space for rug looms, hand looms, pedal Tooms, frames and materiat for basketry, leather work, cord knotting, chair caning, needlework, radio repair and wood work. A full time occupationa? therapist has been employed by the home during most of the time since 1926. This activity was immediately found to be very popular with the patients. The work not only provided creative and useful activity for the patients but provided some income for the patients and the institution. Members of the King's Daughters maintained booths at the State Fairs and other gatherings for the display and sale of the products made by the patients. At all times since the Home was opened the long waiting list kept by the Admissions Committee pointed out the need for expansion. Members were at all times seeking means by which the service rendered might be expanded.

In the Haven Emerson Survey of 1924 , comment was made about the 4From copy of letter sent to members of the Sta
by King's Daughters Circles. Dated January 31,1922 . 
"elegant spaciousness" as inappropriate to an Institution depending largely on public contributions for support. Additional beds were added to bring the capacity to fifty three. It was also reported that the Home for Incurables had excellent cooperative relations with the various voluntary and public agencies, use socia? investigation methods in determining the eligibility of new admissions, and was steadily improving the quality of its care. As the Home was a growing institution with a responsible board and combines many desirable features of la cation, grounds, and bulldings, logical steps to meet the present situation would be the expansion to include all white patients who need institutionat care. 5

The recommendations of this eminent specialist, Dr. Haven Emerson of Boston, gave the Board the needed impetus to go ahead with the building expansion. The plans calted for facilities to double the capacity, new and separate quarters for nurses, a ward for children, isolar tion rooms for contaglous diseases and for the separate care of very sick patients, larger school and assembly rooms, better office and laundry facilities, additional baths and tollets, a chapel, and a garage. In June, 1926, the buflaing was started at an impressive ceremony with Miss Jennie Benedict turning the first spadeful of earth. At this time approximately $\$ 50,000$ had been raised for the new addition. No drive or campaign was put on for the public to raise funds. 6

The new addition was completed and dedicated in June, 1927. At this point the number of patients that coula be cared for was eightyseven. Not only could more patients be accepted but the type of services given improved due to added facilities. 
With the new addition the State Legis7ature in 1.926 increased the appropriation to $\$ 20,000$ a year. This grant plus the money from the Community Chest was spent toward the operation of the institution. Funds for the building program were raised by the members, gifts and legacies from friends.

When the building was completed and there was stilt some indebtedness, Miss Jennie Benedict conceived the idea of "Rainy Day Bags" to raise funds. Many of these bags were made and distributed by Miss Benedict to people throughout Kentucky. A small sum was to be praced in the bag on each day of rain. At an opening of the bags which came two months prior to her death, there was more than three thousand dollars. This was the last work she did for the "Home".7

A Targe house purchased in 1909 in which approximately fifteen persons could be cared, grew into an institution that in 1927 was serving the needs of eighty seven men, women, and children. These patients, all suffering with some incurable disease or disability were given care in an institution that had a Board of Directors and Staff interested in providing "a reat home". The board and various committees spent much time in seeing that the needs of each patient was met. The medicar needs were met by a large staff of doctors from the city giving their services. Religious services were provided by the churches in the city with arrangements by the Religious Committee. A chaper was a part of the new addition.

\footnotetext{
p. 7. 
CHAPTER IV

DEVELOPMENT OF SERVICES 1928-1948

The King's Daughters Home for Incurables were fully aware of the need for an institution to care for the incurable patient as even with the expansions in the past there was still a waiting list of those seeking admission. This prompted the Board of Directors to work even harder to meet the indebtedness on the building addition made in 1927 so further development might be made.

On the twentieth anniversary of the home's founding, the $\$ 27,000$ mortgage was burned. Mayor William B. Harrison, the principal speaker at this event said, "The unlimited capacity to do good is never better exemplified than by this organization." I

The many needs of the patients were constantly considered and met in the best manner possibie. To do this it often meant that members of the Order gave many hours of their time on a voluntary basis. At times when staff was difficu?t to secure, it was not unusual to find King's Daughters workfing among the patients. The House Committee at all times kept constant check on the domestic management of the Home. Because of their good work the building and equipment was always maintained in such a way as to make it a comfortable and attractive place for the patients.

The depression in the nineteen thirties made it impossibie for the Home to operate at its full capacity. A shortage in operating funds made it necessary to close off some rooms and by doing this they were able to still maintain the same high standard of service to the other patients.

The Courier-Journal, Louisville, June 28,1930, p. 1. 
The appropriation from the State Legislature was cut in 1932 from $\$ 20,000$ to $\$ 8,000$. It was later cut in 1935 to $\$ 16,200$. The last reduction came in 1937 when it was cut to $\$ 15,000$. It has remained $\$ 15,000$ since that date even though efforts are made for it to be increased at each meeting of the State Budget Appropriations Committee. 2

The Home faced other financial difficulties in 1936 when an audit requested by the Board of Directors and made by Yeager and White, Accountants, revealed a shortage of $\$ 20,879.28$. This audit covered a period from January ?, 1935 to March 31, 1936. The treasurer for twenty-nine years and the on? y surviving member of the original corporating body of the Home was indicted on charges of embezzing funds and forgery. She plead guilty to the charges and was given probation on a sentence of five years on the recommendation of the commonwealth's attorney. 3 The Maryland Casuarty Company, with which the treasurer was bonded turned over $\$ 72,000$ to the Home for Incurables. 4 The members of the Board of Directors looked upon this as a difficult period as the newspapers during the trial carried full accounts of the events.

At all times since the Home was founded there were some childiren among the patients. Those children that could attended school and the Louisville Police Patrol cooperated in the transportation. There were always those that could not go out and had to be taught in their rooms. The Board of Directors were concerned about the services they were able

\footnotetext{
2Statement of Mrs. E. Tee Heflin, Treasurer of King's Daughters Home for Incurables, personal interview. (This information available in newspaper clippings filed in scrap book with dates of newspapers not recorded,

The Jouisville Times, February 2, 1937.

4 The Herald Post, Louisvil7e, October 26, 1936.
} 
to give the children and in 1940 asked the help of the Community Chest in making a study of the children's program.

The Health Council Committee studied the children's program and found the first child was admitted in 1917 and since then there had been eighty children admitted. In recent years there had been an increase in the number of children cared for, although at no time had they represented more than twenty per cent of the total population of the Home. 5

The committee felt the care given the children was excellent and that the children were individualized. They did not feel the Home provided a healthy atmosphere for young children and adolescents especially the crippled and handicapped who need normal group associam tions. The Home was unable to provide the proper vocational program and lacked personnel to have such a program. It was felt the King's Daughters being a state-wide organization could do more by promoting a well-rounded state-wide program for crippled children. By so doing, they could more adequately carry out the pioneer spirit of the original. founders of the Home for Incurables than by continuing to admit a very few children to the Home when so many, equally in need, are denied any assistance. 6

The Board of Directors considered the report made by the Health Council Committee and since $194 \mathrm{~L}$ have not admitted patients under eighteen years of age.

Miss Nettie Smith, board member and part-time social worker in the Home gave many years of devoted service, both in the volunteer and 
paid capacity. Her duties were described in the By-Laws of the Home:

The Social Worker shall personally investigate al1 applications for admission, see that all application bianks are properly filled out and signed by the President. She shall attend to all business relations between the patients and the Home. She shall have charge of a? ? papers belonging to the patients and shall render any other service desirable for the patient's welfare. She shall perform any other duties the Executive Committee may delegate to her. The Superintendent and the Social Worker shall prepare monthly and annual reports for the Board of Directors. 7

From the duties Iisted and from the reports given the Board of Directors, the activities of the Social Worker constantly demanded a lot of $\operatorname{time}$.

When Miss Smith was forced to resign in 1945 due to $117 n e s s$, the Board of Directors asked the help of the Community Chest in finding someone to continue the work Miss Smith had been doing. Due to a shortage of medical social workers in the community, the Community Chest suggested that the Board of Directors request Family Service Organization to continue with the services Miss Smith had been performing.

The board was interested in clarification of the responsibilities of a social worker. A job analysis was done by Miss Mathilda Mathisen, Associate Professor of Medical Social Work, Kent School, University of Louisville. Miss Mathisen analyzed the job as carried by Miss Smith from the standpoint of distinguishing between clerical and professional activities. 8 It was agreed that Family Service Organization would under take only the professional activities in connection with social investigations

7By-Laws, Section 4, The King's Daughters Home for Incurab?es, Louisvil]e, dated November, 1941. Mathisen, Mathilda, Job Classification of Socia? Workers in The Home for Incurables, A Report to Board of Directors, The King's Daughters Home for Incurables, 1945. 
of new applicants and for case work service to an occasional patient already in the Home when there is some need in change of plan.9 This work was to begin January 1, 1946, and continue for a demonstration period of one year.

This period was extended to nearly three years but at this time the Board of Directors are making plans to employ a Social Worker. The demonstration period of the service given by Family Service Organization pointed out the need for a trained worker in such a position.

In a study of the applications made to Family Service Organization in 1946 and 1947 it was found the majority were in the 60-79 age group and the females out numbered the males two to one. 10 The allotment of beds in the home provides more space for women because of the greater demand. The population of the Home in recent years was made up more and more of the older group. This was especially true when chlldren and under eighteen years were not accepted since 1941.

From time to time the word "incurable" was discussed as being a bad choice. The first discussion came prior to the opening of the institution and came out periodically but with no change. In 1948 this matter was again given consideration and legal advice was secured. It was felt they would lose their identity if the name be changed so it stil? remains The King's Daughters Home for Incurables. 11

During 1948 the By-Laws and Articles of Amendment were revised completely and this word brought out some concern on the part of the

Taylor, Esther M., Memorandum form to Socia? Agencies in Louisville, dated February 2, 1946.

IOT ewis, ope cit., p. 92 .

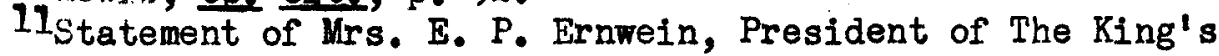
Daughters Home for Incurables, Louisville, personal interview. 
Board of Directors as to the provision of the Home in years to come.

During most of the years the institution has been in operation there has been a long waiting list and this is still true at the end of the year 1948. The board would like to consider plans for building expansion but cannot do this without funds for operation.

The operation costs are met by the $\$ 15,000$ appropriation from the State, Community Chest contributions, King's Daughters Circ]es, and income from patients able to pay for care.

The development of taking pay patients came in the last few years and there is still no official statement as to pollcy. The idea was suggested in the Haven Emerson Survey in 1924 but never put into operation. The Board of Directors still look upon this practice as temporary and hope the time will. come when all can be accepted as charlty. There is no difference in the type of care given free or pay patients.

Persons of all religious faiths are admitted and religious services are made available to each person. There is a large chapel provided for the services with arrangements made by the Religious Work Committee. 


\section{CHAPTER V}

\section{SUMMARY AND CONCIUSSIONS}

This study traced the growth and development of The King's Daughters Home for Incurables in Louisville from the time of its establishment in 1909 through 1948. There had never been a history written on the part it had played in the community. The Board of Directors was anxious to have this study made and the facts compiled in a report. They were concerned over the lack of a history as often they had requests for this type of information. It is hoped that this paper will in some ways serve that purpose and a'so herp evaluate the steps to be taken in future planning.

"The King's Daughters" was organized in 1886 "to develop spiritual Iife and stimulate Christian activities." The organization is of a non-sectarian religious nature. The idea spread rapidy and a group was first organized in Kentucky in 1887. It was this group that started the project of looking after the "sick poor" in the city. Later this grew into the District Visiting Nurse Associam tion.

The nurses of this early group found many incurable invalids in the community not being adequate?y provided for and these facts were presented to the State Convention of King's Daughters in 1908. The need seemed to be so great that they went ahead with plans for the Home for Incurables in Louisville. At first there was the purchase of an acre of ground at Stevens and Norris Avenues in Jouisvitle on which was located an old-fashioned brick building. 
The Home for Incurables was opened in 1909 and was to provide a home for destitute men, women and children who were afflicted with an incurable physical disability or disease and were residents of the State of Kentucky. The institution was owned and operated by the Kentucky Branch of The King's Daughters. Members of the organization were especially active in turning "the old farmhouse" in to "a real home" for the first patients.

The first year of operation was a year of constant struggle to meet the financia? obligations. Then also there was a waiting list of patients desiring admission. Then lawn fetes, entertainments and private contributions failed to raise enough money, the Board of Directors decided to ask the State Legislature for funds. A State approm priation of $\$ 10,000: 00$ made in 1910 provided maintenance and funds for doubling the capacity of the institution.

The need for an institution to care for incurable patients was constantly kept before the eyes of the King's Daughters as there was always more applicants than could be admitted. To he?p correct this, a new addition to the building was made in 1913 which made the capacity forty but there were still others seeking admission.

Another building addition in 1927 brought the bed capacity up to eighty-seven and also provided more adequate facilities for the services rendered.

The Institution is non-sectarian and is owned and operated by the Kentucky Branch of The King's Daughters and Sons. The business affairs of the Home, which is incorporated in Kentucky, are managed and conducted by a Board of Directors. They have continuing power to redelegate its power and authority to committees. There are committees on admission, 
house, rellgious work, occupational therapy, entertainment, finance and by-laws. There is an Executive Committee that supervises the operation of the Home. AlT. members serve on a voluntary basis and give a good portion of time in supervising the work in the institution. The financia? support of the Home came first from members of the King's Daughters and Sons in Kentucky. When this was found to be insufficient in 1910, the State Legislature appropriated $\$ 10,000.00$. The State continued giving this sum until 1926 when it was increased to $\$ 20,000.00$. The appropriation was cut to $\$ 18,000.00$ in 1932 and to $\$ 76,200.00$ in 1936 . In 1937 it was cut to $\$ 15,000.00$ and for the last ten years it has remained the same a'though efforts are made each year to have it increased.

In 1918 when the Louisville Federation of Socia? Agencies was organized, the Home became a member and received over $\$ 6,000$ that had been raised in a joint fund drive. The Home continued to participate when this organization changed to the We?fare League in 1919. These organizations were the beginning of the present Community Chest in Iouisville. Each year the Home received increasingly larger sums from the chest.

Recently there has been additional funds availabie from patients accepted that were able to pay for their care. Any money, real estate, insurance or other income is turned over to the Home.

Soon after World War I the Board made plans for an occupational. therapy program to be added and through this activity many patients are abre to keep their minds and hands busy. The building expansion in 1927 made it possible to have a 7 arge separate room for a shop that has facilities for hand painting, leather tooling, hand loom weaving, 
rug making, machine sewing, woodcraft, chair caning, radio repair, and many other handicrafts. Articles made by the patients are sold by the Home and they share in the profits. Many special activities are provided from money earned in the shop.

Religious services are provided for all faiths and there is an attractive chapel attached to the building.

The medical needs of the patients are supplied by a large staff of doctors from the city of Iouisville. Nursing service is provided by the registered nurse and a staff of assistants. Since the men and women living at the Home for Incurables, in a sense of the word, are sick, they have continuous medical attention.

Children had been accepted by the Home in small numbers until. 1941 when the policy was changed following a survey made by the Heat th Council Committee. Now no person under eighteen jears of age is accepted.

The King's Daughters Home for Incurables is an institution that has served a definite need in the community and State for forty years. It was estab7ished to care for people with some incurable disease or disability. The need for this service is poințed out by the waiting list for those seeking admission. It was started as a King's Daughters project but when additional funds were needed the State Legislature made an appropriation and has continued to do so each year. The Home is a member of the Community Chest and receives funds for the service it gives the peop'e of the city. The institution is recognized by both of these groups as rendering a high quality of personal service。 
The unselfish devotion of the members of the King's Daughters responsible for the management of the Home is characterized by the type of service given the patients. The business and financial matters are adequately discharged. It is the services that affect the day to day living of the patients that the members give much of their time to make it a real home. The bujlding itself is kept clean and attractive. Many additiona' conveniences are added from time to time. Religious services are planned and it is recognized that religion plays a prominent part in the life of many patients. Entertainment to he?p bring pleasure and change of routine is provided.

Occupational therapy gives many patients a new interest in 9 ife and helps create activity necessary for the patients day to day living. There is some concern expressed on the part of some of the present members as to the future management of the Home. Many of the present group have served in various volunteer capacities for long periods of time. Because of this there is some lack of knowledge and interest of younger members in the management of the Home. It will be necessary for younger persons to be entisted in the essentia? voluntary services of management of the home as the persons who have consecrated themselves to the work become no longer able to serve. This is a development of great importance for the continuation of policy-setting and leadership by devoted private citizens which has made it possibre for the Home to provide needed services to the community.

There is a growing awareness of the members for the need of a trained social worker in the institution. Social investigation for determining new admissions was a?ways used but with changing trends in social work practice they saw the need for a trained person on the staff. 
This was further pointed out by the demonstration period made by Family Service Organization in 1946 and 1947. Plans are now under way to employ a social worker to serve the patients in the institution as well as investigate new applicants. During the forty years The King's Daughters Home for Incurables has been in existence it has met a real need in the care of the incurable patients in the community. It has never been able to meet all the needs and some plans should be considered for the expansion of the service. What was probably more important than the service to the community was the service to each patient of the Home. It provided that patient "a real home" where his living with an incurable disease or disability could be cheerfur, pleasant, and happy. 
APPENDIX A

ORIGINAI ARTICIES OF INCORPORATION

THE KINGS DAUGHTTRS HOME FOR INCURABIFS

Apri] 28, 1909

KNOW ALI MEN BY THESE PRESENTS that we, Nancy L. Stucky, Rebecca Smith Buchannan, Eleanor F. Allen, Elizabeth Mittler and Jennie C. Benedict, have united ourselves together for the purpose of organizing a corporation for charitab?e purposes as herelnafter set out:

(1) The name of this Corporation shall be "The Home for Incurables".

(2) The principle office of said corporation is to be in the City of Louisvilie and County of Jefferson.

(3) The object of this charity, which is nonsectarian, is to prom vide a home for persons who are residents of the State of Kentucky, who are afflicted with an incurable physical disability or disease.

(4) This corporation is organized for charitable purposes only, and shall have no capital stock.

(5) The names and places of residence of each of its original incorporators are as follows:

$\begin{array}{ll}\text { Nancy L. Stucky } & \text { Louisville, Ky. } \\ \text { Rebecca Smith Buchannan } & \text { Louisville, Ky• } \\ \text { Eleanor F. Allen } & \text { Louisville, Ky• } \\ \text { Elizabeth Mittler } & \text { Louisville, Ky• } \\ \text { Jennie C. Benedict } & \text { Louisville, Ky• }\end{array}$

(6) The corporation shal7 begin upon the filing of its Artictes for record, and have perpetual succession. 
(7) The officers who shat conduct the affairs of this corporation shall be as follows: A President, First and Second Vice-Presidents, a Recording Secretary, a Corresponding Secretary, a Custodian of Funds, and a Board of Directors of not less than twenty-five, nor more than 100 persons, and the Board of Directors for the first year, or unti? their successors are elected and qualified shall be as follows:

Mrs. Homer M. Stucky,

Miss Lellie V. Hadfield,

Mrs. John H. Stuart,

Mrs. Jas. D. Middleton,

Miss Jennie C. Benedict,

Mrs. Angus W. Gordon,

Mrs. Jas. Buchannan,

Miss Ainslie,

Mrs. S. C. Maxweit,

Mrs. F. W. Keisker,

Miss Kate Barbaroux,

Mrs. T. J. Clancy,

Mrs. Bennett H. Young,

Mrs. Henry E. Tuley,

Miss Fannie Hampton,

Mrs. Bedford Mack?in,

Mrs. E. S. Fisher,

Mrs. E. S. Speed,

Miss Margaret Hollows,

Mrs. Buford Hendrick,

Mrs. Milbur R. Smith,
Mrs. Carl J. Mittler,

Mrs. J. Will Jefferson,

Mrs. Howard Black,

Mrs. C. H. Woodbury,

Mrs. Wibray J. Thompson,

Mrs. Horace Allen,

Mrs. Henry Selmeier,

Mrs. Sam Stone Bush,

Miss Jane Akin,

Miss Elizabeth Martin,

Mrs. Louis T. Davidson,

Mrs. B. C. Milner,

Mrs. B. F. Atchinson,

Mrs. John C. Benedict,

Mrs. C. A. Knollenbury,

Miss Bess Daugherty,

Mrs. Chas. Roberts,

Mrs. Nannie Shy,

Miss Margaret Shaw,

Miss Rosa Lake,

Mrs. L. C. Willis,

Mrs. Harlan K. Fenner 
The officers shall be elected by the Board of Directors on Friday, April 30, 1909 at $30^{\prime}$ clock in the afternoon at 490 Fourth Avenue in the City of Louisvil7e, Kentucky.

(8) The highest amount of indebtedness or liability that the corporation may, at any time, incur shal? be $\$ 50,000$ and the private property of the members, by the provisions of the law under which this corporation is organized, shall not be subject to the payment of corporate debts.

Witness our hands this 20th day: of April, 1909.

Nancy I. Stucky,

Eleanor F. Allen,
Rebecca S. Buchannan

Elizabeth Mittler,

Jennie C. Benedict

Personally appeared before me Nancy L. Stucky, Rebecca Smith Buchannan, Eleanor F. Allen, Elizabeth Mittler and Jennie C. Benedict, each of whom acknowledged her signature to these articles of incorporation to be her act and deed. My commission expires at the end of the next session of the Kentucky Iegislature.

$$
\text { E. A. Overman, }
$$

Notary Public, Jefferson County Kentucky I, Mark A. Gabhart, Clerk of the County Court of Jefferson County in the State of Kentucky, do certify that on this day at 4:02 o'clock P.M., the foregoing Articles of Incorporation were produced to me in my Office and that I have Recorded them, this and the foregoing certificate in my said office.

Witness my hand and seal this 28th day of April, 1909.

Mark H. Gabhart, Clerk. 
APPENDIX B

AMENDED BY-LAWS OF THE KING'S DAUGHTERS HOME FOR INCURABTES

October 8,1948

ARTICIE I

REPEAL AND SUPERSESSION

The By-Laws and all amendments thereto heretofore adopted by The King's Daughters Home for Incurabies, formerly named "The Home for Incurables," are, and each of them is, hereby repealed, and from and after the date of the adoption of these Amended By-Taws, said corporation, its organization and the conduct of its activities and affairs, shall be governed and controlled by the terms and provisions hereof.

\section{ARTICLE II}

MEETINGS

SECTION 7. ANNUAI MEETINGS OF MEMBERS AND BOARD.

The annual meeting of the corporation's members shall be held in January of each year, on a date and at an hour to be specified in the notice of the call of the said meeting, but the time of said meeting shall be prior to the time of the holding of the annual meeting of the corporation's Board of Directors, which latter meeting shall be held on the second Friday of January in each year at an hour to be specified in the notice of the cajt of said meeting.

SECTION 2. REGULAR MEETINGS OF BOARD AND EXECUTIVE COMMITTEE.

Regular meetings of the Board of Directors sha]? be held at 2:30 p. m. 
on the second Friday of each calendar month. Regular meetings of the Executive Committee sha7? be held at 10:00 a.m. on the second Friday of each calendar month.

SECTION 3. SPECIAL MEETINGS OF BOARD AND EXECUTIVE COMMITTEE.

Special meetings of the Board of Directors shall be held at the call of the President or at the call? of the Corresponding Secretary pursuant to the signed written request therefor of ten (10) members of said Board. Special meetings of the Executive Committee shall be held at the call of the President or at call of three (3) members of the Executive Committee.

\section{SECTION 4. PIACE OF MEETINGS.}

With the exception of special meetings of the Executive Committee called to be held elsewhere in Louisville, Kentucky, all of the aforementioned meetings shall be held at the corporation's Home.

SECTION 5. DEVOTIONAL PERIODS.

All of the aforementioned meetings shall. be opened with appropriate devotional periods.

SECTION 6. CALIS OF MEETINGS OF STANDING AND SPECIAL COMMITTEES.

Standing and Special Committees shall meet at the calls of the President and of their respective chairmen, and in the absence of the latter, of their respective Vice Chairmen.

\section{SECTION 7. QUORUMS.}

At meetings of members of the corporation, thirty (30) members, in 
good standing, shall constitute a quorum for the transaction of business. Trenty (20) members of the Board of Directors sha?? constitute a quorum for the transaction of business at meetings of the Board. Six (6) members of the Executive Committee shall constitute a quorum for the transaction of business at its meetings. A majority of the members thereof shall constitute a quorum of Standing and Special Committees for the purpose of transaction of business.

\section{SECTION 8. DECISION BY MAJORITY BATIOT.}

A quorum being present, decisions of the Board of Directors, Executive Committee and other committees mentioned herein in respect to any matter within their respective jurisdictions may be rendered by majority ba1? ot of the members present and voting.

\section{SECTION 9. ADJOURNMENTS.}

Meetings of members of the corporation, of the Board of Directors, of the Executive Committee, and of other committees, may be adjourned if less than a quorum be in attendance thereat, or from day to day if a quorum be present.

$$
\text { SECTION 10. DEFINITION OF MAJORITY. }
$$

A plurality shall constitute a majority as the latter term is used in these By-Iraws.

\section{SECTION 11. PARLIAMENTARY PROCEDURE.}

Procedure at al] meetings shall be conducted in a manner consistent 
with the current edition or revision of Roberts' "Rules of Order," insofar as the same are not inconsistent with these By-Iaws. Appea7s may be taken from decisions of the presiding officer if request therefor is made by two (2) or more members, and decision of such appeals shall be voted upon and made without debate. No member may speak twice on the same subject or motion except by permission of the Chair until each member wishing to speak has spoken. On the call of any two (2) members the yeas and nays shall be ordered, whereupon each member, including the presiding officer, shall vote inless excused by a majority of those present and the resuit of the vote shal be entered on the minutes.

\section{SECTION 12. PROXY VOTING NOT PERMITTED.}

All voting at all of the aforementioned meetings shall be in person, and no voting by proxy sha? 1 be permitted.

\section{ARTICLE III \\ BOARD OF DIRECTORS \\ SECTION 1. COMPOSITION}

The corporation's Board of Directors shall be composed of: The elective executive officers of the Kentucky Branch of the Order of the King's Daughters and Sons; the Leader and one (1) additional representative of each Circle of said Order organized in Kentucky, selected by said Circles, respectively; the Chairman of the Loulsville City Union of said Order; such Iife Members of the corporation as heretofore have been and hereafter may be elected such by the Board of Directors; and fifteen (15) additiona? members, elected at large from members of said order who are residents of jefferson County, Kentucky. 
SECTION 2. DUES.

Each member of the Board of Directors shall pay an annual membership fee of One Dollar $(\$ 1.00)$.

\author{
ARTICLE IV \\ OFFICERS, THEIR SELECTION AND TENURE \\ SECTION 1. ELECTION OF 15 DIRECTORS.
}

The members of the corporation at their annual meeting, shall elect the aforementioned fifteen (15) members at large to the Board of Directors to serve as such for a term of one (1) year and until. their successors are duly elected and accept office.

SECTION 2. ELECTION OF OFFICERS AND COMMITTEE CHAIRMEN.

The Board of Directors, at its annual meeting, sha7r elect a President, First Vice President, Second Vice President, Third Vice President, Recording Secretary, Corresponding Secretary and Treasurer of the corporation, three (3) members at large to the corporation's Executive Committee from their own number and the Chairmen of the Religious Work, Entertainment and Occupational Therapy Committees, to serve as such for a term of one (?) year and until their successors are duly elected and accept office.

SECTION 3. DESIGNATION OF CUSTODIAN OF FUNDS.

The Executive Committee sha77 select and designate a Custodian of Funds, to serve as such for a term of one (1) year and until her successor shall be duly elected and shall qualify and accept office. 
SECTION 4. ELECTION OF VICE CHAIRMEN.

At their first meetings the Admissions Committee, House Committee, Religious Work Committee and Occupational Therapy Committee shal? elect their respective Vice Chairmen.

\author{
ARTICLE V \\ COMPOSITION OF EXECUTIVE COMMITTEE
}

The Executive Committee shall be composed of: The incumbents of the elective executive officers of the corporation, the Chairmen of the Standing Committees, the President of the aforementioned Kentucky Branch, three (3) members of the Board of Directors selected by said Board from their own number, all Life Members of the corporation, and, after her selection, the Custodian of Funds, to serve until their successors are duly se?ected, accept office and qualify.

\author{
ARTICLE VI \\ DUTIES OF OFFICERS \\ SECTION 3. PRESIDENT
}

The President: Sha?l be the chief executive officer of the corporation; shall keep herself informed concerning all of the corporation's activities and the conduct of its affairs and shall be responsible for the proper direction thereof; shall call all meetings which may be required; sha?l preside at all meetings of the members of the corporation, Board of Directors and Executive Committee, and enforce due observance of the provisions of the By-Laws and parliamentary procedure thereat; shall be an ex officio member of all committees; by her 
signature shall authenticate all certificates admitting patients to the corporation's Home, all deeds and contracts and all documents affecting the financial interests of the corporation; shal? countersign al7. checks drawn against the corporation's bank and checking account; shall represent the corporation in all legal. matters; shall appoint special committees as the need arises therefor, and subject to confirmation by the Bxecutive Committee, shall. designate the Chairmen of such special committees; at the annual meeting of the members she shall present a report upon the corporation's activities and affairs during her term of office and make such suggestions as she may deem suitabre to promote the objects and welfare of the corporation and its Home; shall be the custodian of the corporation's seat and shajl affix the same to such documents as may be proper or required; when accompanied by the Custodian of Funds, she shall have access to the safety deposit box containing the corporation's securities and valuables; and shall perform such other duties and discharge such additional functions as ordinarily are performed and discharged by presidents of similar corporations.

\section{SECTION 2. FIRST VICE PRESIDENT.}

In the absence of the President, the First Vice President shall perform the duties of the President. She shall be responsible for the devotiona? periods at the annual meetings of members and Board of Directors and at the regular monthly meetings of said Board.

\section{SECTION 3. SECOND VICE PRESIDENT.}

In the absence of the President and First Vice President, the Second 
Vice President shall preside at meetings of which the President would be the presiding officers if present. She sha77 be Chairman of the Admissions Committee and she shar? preside at all meetings thereof.

\section{SECTION 4. THIRD VICE PRESIDENT.}

In the absence of the President and First and Second Vice Presidents, the Third Vice President shalt preside at meetings of which the President would be the presiding officer if president. She shalt be Chairman of the House Committee and she shall preside at all meetings thereof.

$$
\text { SECTION 5. RECORDING SECRETARY. }
$$

The Recording Secretary shall keep the minutes of all meetings of members of the corporation, of the Board of Directors and of the Executive Committee; shall keep copies of all By-Laws and resolutions that may be adopted; shall have custody of all records of the Board; shall duly attest the corporation's seal when affixed to documents by the President; and shall perform such other duties as are incident to her office.

\section{SECTION 6. CORRESPONDING SECRETARY.}

The Corresponding Secretary sha1] conduct all correspondence pertaining to her office; shall. notify alt officers of the aforementioned Kentucky Branch, a.l Kentucky Circles of mentioned Order, and a 11 independent members of said Order residing in Kentucky, of the time and place of the annual meeting of members of the corporation; shall notify a?1 persons of their election to the Board of Directors, to the Executive Committee and to offices of the corporation; and shaln notify all 
persons appointed to the Home's Medica? Staff and to the Men's Advisory Committee.

\section{SECTION 7. TREASURER.}

The Treasurer shall receive all money pald to the corporation and keep accurate accounts of all of the corporation's funds, receipts and disbursements except such of same as are entrusted by the Executive Committee to the Custodian of Funds. All disbursements of the corporation's funds shalt be made and evidenced by checks signed by the Treasurer and countersigned by the President. Except in cases of emergency expenditures, no disbursements shall be made otherwise than pursuant to authorization from the Executive Committee. Elaergency expenditures disbursed by the Treasurer without the Executive Committee's prior authorization shall be promptly reported by her in writing to the next regular meeting of the Executive Committee. The Treasurer shall be Chairman of the Finance Committee. She shall make monthly and annual reports to the Board of Directors. Before entering upon the discharge of her duties, the Treasurer shall qualify by executing a fidelity bond in favor of the corporation in a penal amount and with corporate surety thereon satisfactory to and approved by the Executive Committee. The premium incident to said bond shalr be paid by the corporation.

\section{SECTION 8. CUSTODIAN OF FUNDS.}

The Custodian of Funds shall have custody of such funds and securities as from time to time may be entrusted to her by the Executive Committee. She shall make, maintain and alter investments of said funds as directed by the Executive Committee. Before entering upon the discharge of her 
duties, the Custodian of Funds shalt qualify by executing a fidelity bond in favor of the corporation in a penat amount and with corporation surety thereon satisfactory to and approved by the Executive Committee. The premium incident to said bond shall be paid by the corporation.

SECTION 9. ANNUAT, REPORTS.

A17. officers and Committee Chairmen shall present written reports to the annual meeting of the members of the corporation concerning the conduct of the activities and affairs of their respective offices and committees.

\section{ARTICLE VII}

DUTIES OF THE EXECUTIVE COMMITTEE

The Executive Committee: (a) Shall have immediate supervision of the conduct of all of the corporation's activities and affairs, and in the interim between meetings of the Board of Directors shall have all of the powers of said Board, except that the Executive Committee shall have no power to amend the corporation's Articles of Incorporation or By-L8ws:

(b) Shall receive reports from the Treasurer in respect of emergency expenditures and shal] ratify and confirm such of same as it may deem to have been properly made;

(c) Shall receive and study the Finance Committee's budget report and recommendations and transmit the same, with its recommendations, to the Board of Directors; 
(d) Shalt select and designate a Custodian of Funds as provided in Section 3, Article IV hereof, and shall entrust to her such funds and securities as it may deem proper for safe keeping, investment and reinvestment and shal give the Custodian of Funds appropriate instructions with respect thereto;

(e) Shall make appropriate recommendations to the Board of Directors with respect to reports of the House Committee concerning major repairs, improvements and supplies and contractors' bids therefor, and shall take action on such bids as provided in Section 2, Article VIII hereof;

(f) Shall take action in respect of fllling vacancies as provided in Section 2, Article IX hereof;

(g) In its discretion shalt approve or reject:

(1) The fidelity bonds berein mentioned: and

(2) Recommendations of the Admissions Committee concerning admission of applicants as patients;

(h) At its regular meeting in November of each year, shall select the Nominating Committee mentioned in Section 8, Article VIII hereof.

Subject to review by and approval of the Board of Directors, the Executive Committee:

(i) Shall authorize the safe keeping, investment and expenditure of a]7. of the corporation's funds and monies;

(j) Shall select and designate the members of the Admissions, House, Religious Work, Occupational Therapy, Entertainment, Finance and ByLaws Committees and the Chairman of the last named Committee; 
(k) Shall employ a Superintendent for the Home;

(1) Sha]? employ a bookkeeper or engage bookkeeping services, and annually shall have all of the corporation's books audited by a competent auditor and accountant;

(m) Shall appoint a Medical Staff for the Home;

(n) Shall select the Medical Coordinating Committee, mentioned in Section 9, Article VIII hereof;

(o) On recommendation of the Admissions Committee, shall employ a social worker;

(p) On recommendation of the Occupationat Therapy Committee, may employ a therapist;

(q) May employ a fult time office secretary;

(r) May appoint a Men's Advisory Committee, composed of the Home's Chief of the Medical Staff and such other members as the Executive Committee may detormine.

No establishment of salary or wage scales, and no change in the salaries or wages paid the corporation's employees shall be effective unless and until approved by the Executive Committee or Initiated and rendered effective by proper action of the Board of Directors.

ARTICIE VIII

STANDIMG COMMITTEES

SECTION 1. ADMISSIONS COMMITTEE.

The Admissions Committee shall be composed of the Second Vice Presim dent, who shall serve as Chairman thereof, and of four (4) additional members selected by the Executive Committee. The Admissions Committee shall make proper and adequate investigations in respect of all. applications 
for admission of patients to the Home, thereafter this Committee shall make appropriate recommendations to the Executive Committee in respect of such applications, and in cases in which such applications are approved by the Executive Committee it shall be the Admissions Committee's responsibility to take care that all required and proper documents are properly signed, executed and delivered before the applicants concerned are admitted to the Home. In recommending admission of applicants, the Admissions Committee shall be governed by the ellgibility requirements provided in Article XI hereof. In cases of genuine emergency the Admission Committee shall have authority to authorize the admission of patients, and in such cases this Committee shall report its action and reasons therefor to the next succeeding meeting of the Executive Committee. Except in such cases of emergency the Admissions Committee shall consider applications for admission in the order in which the same appear upon the Home's waiting 11st. In the event of vacancies, the Admissions Committee is authorized to admit patients to the Home in the interim between meetings of the Board of Directors and Executive Committee. By its Chairman this Committee shall report its activities to the Board of Directors to the latter's annual and regurar monthly meetings.

The Admissions Committee shall keep itself informed concerning the physica? and mentar conditions of the patients and shal? have charge of patient's burials.

The Admisaions Committee shall make appropriate recomnendation to the Executive Committee with respect to the employment and discharge of the social worker. 
SECTION 2. HOUSE COAHITTEE.

The House Committee shal? be composed of the Third Vice President, who shall be 1ts Chairman, and of four (4) additional members who shall be selocted by the Executive Committee. The House Committee sha?l keep itself advised and informed of the domestic management of the Home. After consulting with the riome's Superintendent with respect to the Home's needs and requirements therefor, the House Committee shall Invite competitive bids for al1 major repairs, improvements and supplies; shall report the bids so recelved to the Executive Committee, which in turn wil make its recommendations with respect thereto to the Board of Directors, which in its discretion will authorize acceptance or rejection of such bids.

SECTION 3. REIIGIOUS WORK COMMITTEE.

The Religious Work Committee shall be composed of a Chairman, elected by the Board of Directors, and of three (3) additional members selected by the Executive Committee. It shall be the duty of this Committee to arrange for 0.11 religious services conducted in the Iome except those for which provision is made in Section 2, Article VI hereof, and to oversee the spiritual welfare of the patients.

\section{SECTION 4. OCCUPATIONAL THRRAPY COMMITTEE.}

The Occupational Therapy Committee shart be composed of a Chairman, elected by the Board of Directors, and of two (2) additional members, selected by the Executive Committee. It sha7.7 be the Occupational Therapy Committee's duty to supervise the work of the Home's Occupationa? 
Therapy Department. This Committee shall recommend to the Executive Committoe the employment and discharge of the Occupational Therapist. SECTION 5. ENTERTAINMENT COMMITTEE.

The Entertainment Committee shal? be composed of a Chairman, elected by the Board of Directors, and of two (2) additional members selected by the Executive Committee, and it sha?? be its duty to provide appropriate entertainment for the patients.

\section{SECTION 6. FINANCE COMMITTEE.}

The Finance Committee shall be composed of the corporation's Treasurer, who shall serve as its Chairman, the Custodian of Funds and of three (3) additional members selected by the Executive Committee from among their own number. It shall be the Finance Committee's duty to have intimate knowledge of the corporation's which its funds are to be used and employed, to make appropriate recommendations to the Executive Committee with respect to expenditures, investments and reinvestments of the corporation's funds and monios, to see that all of the corporation's debts and obligations are promptly paid and satisfied, that proper receipts are obtained and filed with respect to disbursements and payments made; to prepare the corporation's annual budget and to report its recommendations with respect thereto to the Executive Committee.

SECTION 7. BY-LAWS COMMITTEE.

The By-Laws Committee shall be composed of a Chairman and of four 
(4) additional members, a77 selected by the Executive Committee from among the latter's own number. It shall. be the By-Laws Committee's duty to make a continuing study of the corporation's Artic'es of Incorporation and amendments thereto, and of its By-Laws and amendments thereto, with view to presenting to the Executive Committee and Board of Directors recominendations concerning revisions thereof deemed requisite to maintain the same in appropriate form and substance.

\section{SECTION 8. NOMINATING COMMITTEE.}

The Chairman and members of the Nominating Committee sha7? be selected and designated by the Executive Committes, which sha71 select two (2) members of the Board of Directors who are not members of the Executive Committee and one (1) additional member from among their own number. It shall be the Nominating Committee's duty to present to the members' annual meeting the names of not less than thirty (30) women, possessing the eligibility qualifications described in Section 1 Article III hereof, as candidates for election of fifteen (15) of their number to the Board of Directors as the members at 1 arge thereon, and to present to said Board, at its annual meeting the names of not less than two (2) women as candidates for each of the elective executive offices of the corporation and as Chairmen of the ReTigious Work, Occupationa?. Therapy and Entertainment Committees.

SECTION 9. MEDICAL COORDINATTNG COMMITTEF.

The Medical Coordinating Committee shall consist of the Chairman of the Admissions Committee, who shall serve as its Chairman, likewise, 
and of two (2) additional members, to be se?ected by the Executive Committee. It shall be the duty of the Medical Coordinating Committee from time to time to meet with a committee of the Home's Medical Staff with a view to coordinating the management of the lome and the services rendered by the Medical Staff, to obtain interchanges of information and ideas, to serve as a medium by which the Medica? Staff's views the more readily may be communicated to the Executive Committee and Board of Directors, all to the end of improvement of the services rendered by the Home to its patients.

\author{
ARTICIE IX \\ FILIING OF VACANCIES \\ SECTION I. EXECUTIVE OFFICES.
}

All vacancies occurring in elective executive offices shall be filled for their respective unexpired terms by election of the Board of Directors.

\title{
SECTION 2. OTHER INCUMBENCIES.
}

Vacancies in the office of the Custodian of Funds, vacancies occurring among the fifteen (1.5) directors at large, vacancies upon the Executive Committee and Standing and Special Committees shall be filled for the respective unexpired terms by selection of the Executive Committee, which shall report action so taken by it to the nest succeeding regular meeting of the Board of Directors.

\section{SECTION 3. NOTICE OF CANDIDACIES.}

The names of candidates proposed to fill. such vacancies shall be announced at the meeting of the body authorized to fill? the same held 
next preceding the meeting at which successors are to be selected.

ARTICLE X

LIFE MEMBERS

Members of the Order who have rendered long and outstanding service to the Home sha7t be eligible, in the discretion of the Board of Directors, to be elected Iife Members of the corporation in recognition of such services. Iife Members shall be life members of the Board of Directors and Executive Committee, and sharr be entitled to full voting privileges at all meetings of members of the corporation, Board of Directors and Executive Committee.

\section{ARTICLE XI}

ELIGIBILITY QUALIFICATIONS FOR ADMISSION AND RESIDENCE OF PATIENTS; DISMISSAI REGULATIONS. SECTION 1. ELIGIBILITY.

No applicant for admission to the Home as a patient thereof sha?t be so admitted unless such applicant be a needy person, not less than 18 years of age, of good character, irrespective of religious denomination or affiliation, or non affiliation, nor unless such applicant shal? have been a citizen and resident of the Commonwea?th of Kentucky for not less than one (I) year next preceding his or her application for such admission nor unless such applicant be afflicted with an incurable physical disability or disease. No such applicant shall be admitted who has been neither dismissed from a hospital as incurable nor pronounced incurable by an attending physician. Applicants shall not be admitted until they have been examined and approved by the 
corporation's attending physician or a member of its Medica? Staff. No such app?icant sha? ? be admitted who is afflicted with a mental derangement, a drug or liquor habit, a contagious or infectious disease, or cancer. No applicant shall be admitted who is possessed of assets or resources of any kind or character whatsoever adequate for purposes of such applicant's necessary support, care and attention, or who has relatives who are able to provide for him upon whom the applicant has a legal, natural or moral claim for support.

\section{SECTION 2. PROBATION.}

All applicants shall be admitted on probation for a period of not less than one (1) month.

\section{SECTION 3. TRANSFER OF ASSETS.}

Applicants possessed of property or estate of any kind or character whatsoever, including contracts for the payment of insurance benefits, or annuties, or entitled to other income of whatsoever nature or description (all hereinafter referred to as "estaten) upon being admitted as patients shall convey, transfer and assign all such estate to the corporation and shall enter into an agreement with the corporation to convey, transfer and assign to the corporation any and all such estate which thereafter may come to their possession or to which they thereafter may become entitled. All appifcants admitted to the Home as patients shall sign, execute and deliver appropriate contracts and documents effecting the conveyances, transfers and assignments aforementioned, and embodying the substance of the provisions of this present Article. 
SECTION 4. RULES COVERING PATIENTS.

No patient shal? be permitted to bring or to have brought into the Home any intoxicating Ifquor or drug, or to have the same in his or her possession except when the same shall have been prescribed by the corporation's attending physician or a member of its Medical Staff. Under the direction of the Superintendent of the Home, patients will be required to perform such services in the Home as they may be capable of rendering, their respective conditions considered.

SECTION 5. DISMISSAI AND DISCHARGE OF PATIENTS.

Al1. patients shall be subject to the rules of the Home and for the repeated and continued violation thereof shal? be subject to dismissa? and discharge therefrom. Any patient who becomes rehabilitated, and any patient who in the opinion of the Chief of the Home's Medica? Staff is deemed an unsuitable case for retention in the Home, shall be subject to dismissat and discharge therefrom.

SECTION 6. RESTORATION OF UNEARNED TRANSFERRED ASSETS.

In the event of dismissal or discharge, or voluntary withdrawal, of a patient from the Home there shall be refunded and restored to such patient the estate theretofore conveyed, transferred and assigned by such patient to the Home, or the fair value of such thereof which then is not available in kind, after deduction therefrom of an amount equal to the fair and reasonable value of the hospitalization, care and attention afforded such patient in the Home. 
ARTICIE XII

FISCAT YEAR

The corporation's fiscal year shall commence each January ist and shall continue to and including the next succeeding December 31 st.

ARTICIE XIII

CORPORATE SEAL

The corporation shall have a metal impression sea?, circular in shape, displaying near the center of the circle a conventiona? Maltese Cross bearing the initials "I. H. N.", displaying outside the Cross" margins the words "Corporate Seal," and displaying near the margin of the seat's circumference the words, "The King's Daughters Home for Incurables."

\section{ARTICIE XIV}

MORTGAGING OF PROPERTY

The corporation shall. not create any mortgage on property owned by it nor acquire any property the purchase of which would require a mortgage, without first securing the approval of the Board of Directors of the Community Chest, of Louisvijle, Kentucky.

\section{ARTICIE XV}

\section{AMENDMENTS}

These By-Iaws may be amended at any regular meeting of the Board of Directors at which a quorum is present, by a two-thirds vote of those present and voting, provided that the proposed amendment sha?I 
have been read at the preceding regular meeting of the Board and announcement made by the Chair thereat that the proposed amendment would be put to vote at the Board's next succeeding regular meeting. Authenticated: 1948

Recording Secretary 


\begin{abstract}
APPENDIX C
ARTICIES OF AMENDMENT OF THE HOME FOR INCURABLES

October 8, 1949

KNOW ALI. MEN BY THESE PRESENTS:
\end{abstract}

That we, the undersigned, being two-thirds of the duly elected and qualified directors of The Home for Incurables, a Kentucky corporation, acting pursuant to a resolution duly adopted by said corporation's Board of Directors at a regular meeting of said Board, held 8th day of October, 1948 and so adopted by the affirmative vote of tro-thirds of the directors present thereat, and the amendment herein mentioned having been read at the previous regular meeting of said Board, held loth day of September, 1948 and having been incorporated in the minutes of said two (2) meetings, do hereby amend the said corporation's Articles of Incorporation, as heretofore amended, as follows, to-witt:-

\title{
A DELETION AND SUBSTITUTION
}

The several numbered paragraphs and articles of said original Articles of Incorporation, and the several amendments thereto hereto fore executed, filed and recorded, and each and every word and figure thereof are, and each of them is, thereby deteted and expunged therefrom, and the following terms and provisions are substituted in lieu thereof.

\section{B. PRESENTLY EFFECTIVE PROVISIONS}

I. NAME. The said corporation is named, and hereafter shall be known as, "The King's Daughters Home For Incurables." 
II. OFFICE. The principal office and place of business of said corporation shall be in the City of Louisville, County of Jefferson, State of Kentucky.

III. PROCESS AGENT. EIIa P. Ernwein, who resides at 248 South 43rd Street, in the City of Louisvilie, County of Jefferson, State of Kentucky, is said corporation's resident agent and its authorized agent upon whom process can be served.

IV. NON-STOCK, CHARITABLE CORPORATION. Said corporation does not have, and shall not have, any capital stock, and is organized under the provisions of Chapter 273 of Kentucky Revised Statutes for the charitable purposes herein specified.

V. OBJECTS. The objects and purposes of said corporation are and shall be solely and exclusively charitable, and are and shall be accomplished and realfzed by providing, maintaining and conducting a home for needy persons of good character, irrespective of their religious denominations or affiliations, or non-affiliation, who have been citizens and residents of the Commonwea? th of Kentucky for not less than one (l) year next preceding their respective applications for admission to said home and who are afficted with an incurable physical disability or disease; provided, however, that all such contemplated patients shall be admitted to said home, and shall continue as patients thereof, only in conformity with such rules, regulations and eligibility qualifications as from time to time may be prescribed by said corporation's Board of Directors, or pursuant to said Board's redelegation of authority, to officers of said corporation and to committees of its members, to prescribe the same. 
VI. NON-PROFIT CHARACTER. The corporation is not organized and its affairs shall not be conducted for pecuniary profit; the corporation shatl not be used or employed for gain by any person or corporation and its income shall be devoted solety to the charitable purposes and objects aforesaid; no private pecuniary profit sha7? be derived from the corporation by any member; no part of the corporation's net earnings sha? I inure to the benefit of any member or individual; and no substantial part of the activities of the corporation shall consist in carrying on propagande or otherwise attempting to influence legislation. Upon the termination of said corporation's existence by reason of its voluntary dissolution, or is any other manner or for any cause whatever, all of said corporation's monies, properties and assets of every kind, character and description whatsoever remaining after the payment and satisfaction of the corporation's debts, obligations and Tiabilities forthwith shall be conveyed, transferred, assigned and set over to the Commonwealth of Kentucky for the purposes of the continuation of the activities and functions of the aforementioned home and the attainment of the objects and purposes aforesaid, and in the event the said Commonwealth declines to accept said monies, promptly and assets so remaining upon the terms and conditions aforementioned, then the same forthwith shall be conveyed, transferred, assigned and set over absolutely to the Commonweal th of Kentucky for inclusion and merger in said Commonwealth's funds devoted to maintaining and operating hospitals maintained by said Commonwealth and for use, employment, expenditure and exhaustion as part of said funds.

VII. MEMBERSHIP. AlT members in good standing of The Kentucky Branch of the Order of The King's Daughters and Sons shall be members 
of this corporation and shall be entitled to vote at al? meetings of members of said corporation.

VIII. BOARD OF DIRECTORS-POWERS. The business and affairs of said corporation shall be managed and conducted by a Board of Directors, which shall have continuing power to redelegate its powers and authority to committees, officers and representatives of the corporation, to rescind and abrogate all such redelegations, and to make, amend and repeal By-Laws governing the manner in which the business and affairs of the corporation shall be conducted.: The eligibility qualifications of members of said Board, the number of directors to constitute said Board, the time and place of their election, the duration of their terms of office and manner of filling vacancies on the directorate shatl be prescribed by By-Iaws.

IX. INCUMBENTS TO CONTINUE IN OFFICE. The elective and appointive officers of this corporation who hold office at the effective date of these Articles of Amendment shall continue to hold their respective offices for remainder of the terms to which they respectively were elected or appointed and until their successors are duly elected or appointed, as the case may be, and have qualified in conformity with the corporation's By-Laws.

X. PERPETUAL EXISTENCE. The corporation shall have perpetual existence and succession.

XI. INDIVIDUALS' NON-LIABILITY. The private property of the officers, directors and members of said corporation shall not be subject to payment of any debt or 7 lability of sald corporation.

In Testimony Whereof, Witness the signatures of the undersigned, 
signed and subscribed to multiple copies hereof, each to have the force and effect of an original, at Louisville, Jefferson County, Kentucky, this 8th day of October, 1948. 
APPENDIX D

PRESIDENTS OF KING'S DAUGHTERS HOME FOR INCURABLES

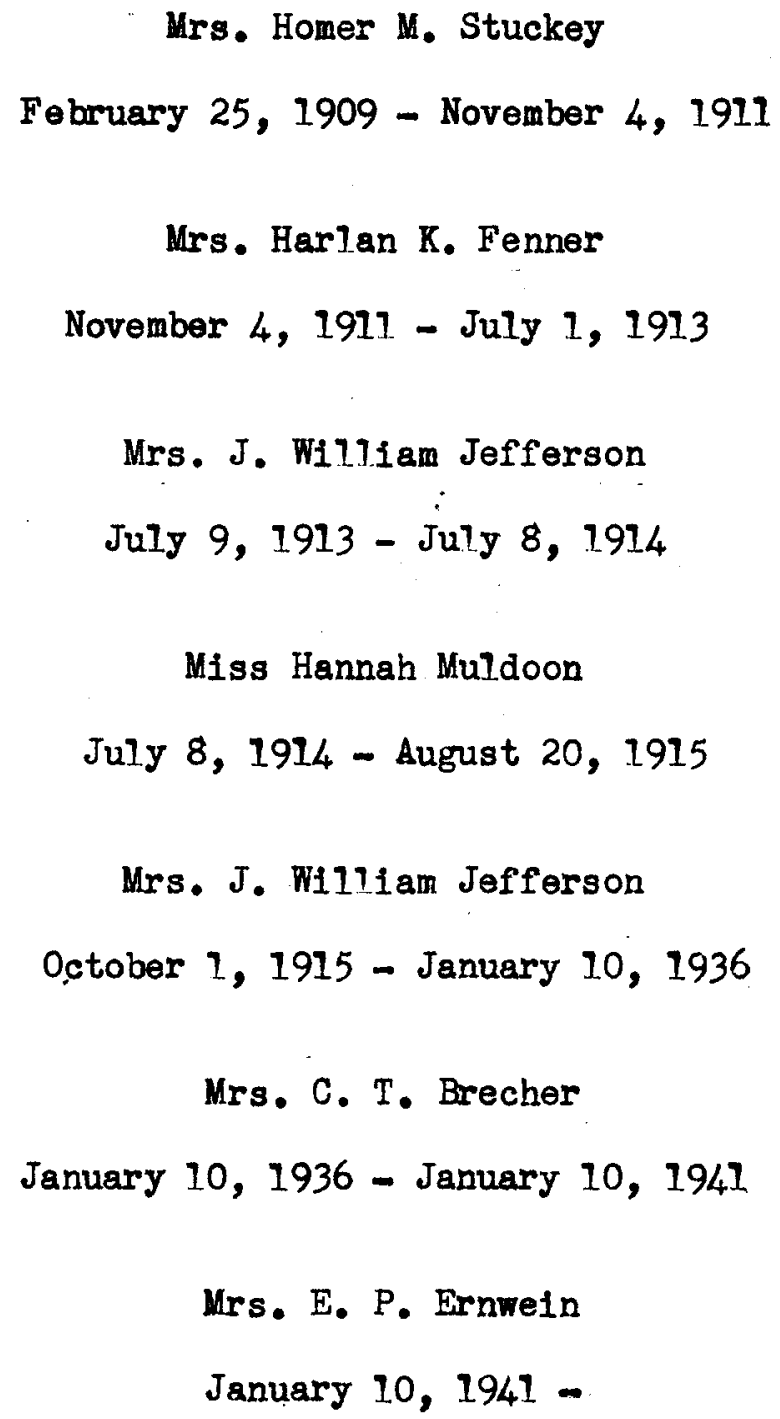


BI BLIOGRAPHY

Books

De Kruif, Paut Henry. Why Keep Them A71 ve? New York: Brace and Co., 7936.

Gugle, Sara F. History of The International Order of The King's Daughters and Sons. Columbus: Stoneman Press, 1931.

Slingerlard, W. H. Child Welfare Work in Iouisvi17e, A Study of Conditions, Agencies, and Institutions. Louisvi71e: Welfare Teague, T919.

\section{Public Documents}

Office of the County Clerk, Jefferson County, Kentucky. Articles of Incorporation of the Home for Incurables. Original Artic7es dated Apri1 28, 7909, Amended November 6, 1939 and September 73, 1935.

Office of the County Clerk, Jefferson County, Kentucky. Articles of Amendment of The King's Daughters Home for Incurables, dated October 8, 1.948 .

Office of the County Clerk, Jefferson County, Kentucky. By-Laws for Home for Incurables, dated November, 1947 and amended October $8,1948$.

\section{Reports}

Emerson, Haven, and Fhillips, Anna C. Hospitals and Health Agencies of Louisvi77e, 1924, A Survey. A Report for The Hea?th and Hospita? Survey Committee of the Touisvilie Community Chest, Louisvi ??e, 1925.

Health Council Committee. A Report on "The Children's Program at The Home for Incurables". Touisvi7?e: November, 1940.

Kentucky Branch News, I. H. N. The King's Daughters and Sons. Monthly Reports to Members 1929 to 1935. (Mimeographed).

Welfare League, Annual Reports of the Jeague and Its Member Organizations, Louisvi17e, 1919, 1920, 1921, and 1922. 


\section{Articles}

Boas, Ernest P. "The Care of the Chronical'y Ill", Reprinted from The Proceedings of the Nationa 7 Conference of Social Workers, Columbia University Press, New York: 1939.

But'er, Charles and Franklin, I. M. "Chronic Disease Patients, Housing Them Targe Scale", Modern Hospital, Vol. IV. No. ', January, 7940 , pp. 67-73.

Hornola, F. M. "King's Daughters Home", The New Highlander, Vol. I, No. 7, August 1, 7928, pp. 1-2.

Fenner, Har'an K. "The King's Daughters Home", The Sunbeam, Vol. XXV, No. 9, May, 7919.

Ferguson, Dewit, "Maryland Evaluates Iicensing of Agencies and Institutions", Public Welfare, Vol. IV, No. 10, October, 1946.

Mionehouse, Clara. "A Short History of the Order," The Silver Cross, $\mathrm{X}$, July 1924, pp. 9-16.

"Wiomen and Incurabres", The Community, Vo7. II, No. 2, February 1919, p. 2 .

\section{Unpublished Material}

Brown, Gretna Iillian. "The Place of Rehabilitation in The Home for Incurab?es". Unpublished masters thesis, Kent School of Social Work, University of Louisvil1e, 1948. Pp 66.

Carr, Dinard S. "The Problem of the Chronical'y IT' in Louisville, Kentucky, 1946." Unpublished masters thesis, Kent School of Social Work, University of Iouisvil7e, 1946. Pp. 247.

Tewis, Elizabeth Conder, "A Study of One Hundred and Forty King's Daughters Home for Incurables Applicants Served by Family Service Organization January 7, 1946-December 31, 1947." Unpub7ished masters thesis, Kent School of Socia? Work, University of Louisville, 1948. Pp. 103. 